\section{CONSIDERATIONS ON CHOLERA IN EGYPT IN RELATION TO SOME ALTERATIONS OF THE INTESTINES.}

By P. SONSINO, M.D. PisA,

HONORARY AND CORRESPONDING MEMBER OF THE EPIDEMIOLOGICAL SOCIETY OF LONDON.

IN a special article in THE LANCET of June 6th reference is made to the present epidemic of cholera in Egypt, especially as regards the insanitary condition of the towns and villages of that country, and particularly of Alexandria, and also the various conflicting interests, the fanaticism, \&c., which render useless any actual and rational attempts to stamp out the epidemic. It is certainly admitted by all the best hygienists that the only means to oppose an outbreak of cholera or the spread of it, so as to keep it from becoming epidemic, is to put the country in a better hygienic condition in every respect, and especially to better the conditions of sanitation respecting excreta. When these conditions are at fault it is not possible to obtain any good result during the continuance of an epidemic. In the same manner it is impossible for any able and brave general to gain a victory if his men are not previously prepared to sustain the battle. Measures such as quarantines, lazarettes, segregation, and even destruction of the germs-partly from the difficulty of their application, especially in a mixed and not uniformly ruled population and partly from the opposition exhibited by an ignorant and fanatical population-as THE LANCET rightly observes, are after all insufficient, as the germs are too subtle either to stop at the borders of a country or to be destroyed totally, whenever they have beer already introduced. India, the birth-place of cholera, has taught all this, and it is desirable that its teachings should be understood and utilised by the rest of the world better and more completely than they have been up to now. But for Egypt there are some special sources of danger from cholera that claim the special attention of those that rule sanitary matters, and I think it useful to recall them to the attention of the readers of THE LANCET, as it seems to me that they are altogether overlooked at present by the sanitary authorities of that country. We cannot say as a general statement that kgypt is disposed to cholera more than any other part of the world. Nay, if we judge from all that has happened in this last half century, and considering that Egypt is on the high road between India and Earope, we may say that cholera appears to attack Egypt rather with less frequency than many other Mediterranean countries. Indeed, if I remember well, Egypt in this second half of the present century has had only three epidemics of cholera besides the present one. And this last (1895-96) began twelve years after the previous one of 1883, whllst in that interval of time cholera had ravaged other Mediterranean countries without extending to Egypt. But if Egypt is not predisposed more than other countries to the attack of cholera, yet it is ravaged by its outbreaks with more vehemence and greater death-rate than many other countries perhaps more frequently attacked. It suffices to remember that cholera in 1865 destroyed there no less than 60,000 people, and in 188350,000 people, in a space of three months. Now ; is a good rule on studying an epidemic to take into due consideration not only the influences that act generally every where, but to inquire which are those special influences which modify in each particular country the general influences and give particular features to an epidemic. Besides the generally bad hygienic conditions of Egypt upon which the article in THE LAXCET has dwelt there are some peculiar conditions of that country which, I think, explain well why cholera epidemics in Egypt are so widely spread and produce so much mortality amidst the native population. Before all I would mention a condition that is not entirely peculiar to Egypt-namely, the presence of a great river, which is the only source of the water supply for drinking and all other purposes for the entire population. Lord Cromer's latest report to the Egyptian Government affords many reasons for hoping that this noxious influence may be done away with in the near future, and he expresses a wish that a new supply of water may be afforded everywhere to the country by the

\footnotetext{
1 See Macnamara on Cholera in Davidson's Hygiene and Diseases
}

construction of artesian wells, which will give a water quite pure from micro-organisms. But apart from this detrimental influence of the polluted water of the river, from which only the well-to-do class of Europeans can exempt themselves by boiling the water, and which from many causes cannot be wholly at once suppressed during the continuance of the epidemic, we bave in Egypt another more peculiar influence that I think plays a great part in producing a widely spread morbidity and mortality from cholera among the native population. This deleterious influence is exercised by the previous morbid conditions of the intestines of the larger number of the natives in Egypt, due to the effects of dysentery, bilharzia, and ankylostoma, and other intestinal worms, which favour greatly an attack of cholera and its fatal issue. Cholera in fact is a disease that, like several other infectious diseases, begins from the prime vice. The introduction of the comma bacillus (at present the recognised cholera-producing germ) is made only by the way of the mouth; its seat is the intestines; the first pathological alterations due to cholera are in the walls of the intestines only; cholera is thus in its beginning an intestinal disease only and the alteration and disorders of its subsequent stages are not the direct effect of the comma bacillus, since cholera bacilli are not present either in the blood or in any of the tissues of the body except the intestines (Macnamara), but only the effects of toxins tiat are produced by the same bacillus. Now the conditions of the stomach which render this viscus unable to destroy comma bacillus, as it is by the healthy gastric secretion and the states of the intestines which facilitate the multiplication of the comma bacillus and its penetration through their walls, are the peculiar conditions which to my mind appear to favour an attack of cholera and aggravate it in the native Egyptians. These conditions are set up by special changes, as chronic catarrhs or inflammations, with solutions of continuity that are produced in different parts of the intestines by bilharzia, ankylostoma, rhabdonema, and by other intestinal worms and especially by dysentery. It is true that the part of intestine more generally attacked by cholera bacillus is the ileum, whilst ankylostoma and rhabdonema attack rather the first part of the small intestine and bilharzia and dysentery the entire large intestine ; but when a process of inflammation has existed for a long time in any part of the intestine it is certain to affect the functions of the neighbouring part of the same viscus, so that everyone that already suffers or has suffered from intestinal disorders may a prior $i$ be supposed to be more exposed to an attack of epidemic cholera and to be more in danger than any individual that has not so suffered.

In an account that $I$ have given of the epidemic of the cholera of $1883^{2}$ in Cairo I mentioned cases in which severe lesions of the large intestines due to previous dysentery have been found associated with those of the small intestine due particularly to cholera, and I spoke of the frequency of bilharzia and ascaris found in the dead bodies of the cholera patients. In the same manner I found a great number of different species of worms in the bodies of horses that died from the severe epizootic of 1876 in Egypt, ${ }^{2}$ and $I$ then entertained the idea tbat the disease was not caused by the worms, but that this parasitism, by diminishing the resistance of the organism, predisposed to the attack of the epizootic disease and to the fatal issue of it. It then follows that if the natives of Egypt were not beforehand affected by those intestinal alterations due to the presence of worms or to dysentery, which now some pathologists consider to be caused by amoebæ, the epidemic of cholera in Egypt would probably be less extensive and less productive of large mortality. But in view of diminishing the zooparasitic diseases in Egypt it would be necessary to begin with appreciating more their importance, to instruct more accurately about them the old and new native sanitarians of Egypt, and to institute a special board attacbed to the sanitary department for contriving rules of sanitation and enforcement of them throughout the country. The want of this is a special defect in the sanitary institutions of Egypt, to which due attention bas been not yet given by the rulers of the country. Indeed, just lately we have seen that for the choice of the pathologist at Kasr-el-Aini Hospital they

2 Sul Cholera in Cairo d'Egitto nell' Anno 1883. Ricordi. Comunicazione fatta alla Accademia Medico-Fisica Fiorentina nella sedut del 13 Luglio, 1884. Pisa, 1884

3 On the Entozoa of the Herse in Relation to the late Egyptian Equine Plague. By P. Sonsino, M.D. Pisa. In the Veterinarian for February and March, 1877. 
170 The Lancet,] DR. T. FISHER: MITRAL REGURGITATION FROM VALVULAR DISEASE. [JULy $18,1896$.

have only relied on the fact of his being a skilled bacteriologist, though quite new to Egyptian practice and experience, and a Sanitary Institute has been lately established, but with a staff which leads one to suppose that it will be a mere laboratory for bacteriological researches. Moreorer, in the article of THE LANCET it is stated that the Egyptian Government has recently requested the Pasteur Institute to send a mission to Cairo to make experiments with a new anti-cholera serum. I suppose that this predilection for bacteriological studies and researches alone is not the fault of the present distinguished and enlightened chief of the sanitary administration, but it is to be ascribed to an erroneors interpretation of the value at present attaching to the pathological researches in some countries of Europe and to the misleading influence exercised by foreign scientists on the native governmental authorities of Egypt, who are too prone to follow European tendencies instead of adapting their conduct to the peculiar wants of the Egyptian people. Bacteriology has already too many able researchers in old Europe to want the special help of researches to be made in Egypt, where there is scarcely a special disease that falls in the domain of the bacteriologist which cannot be studied even better in any other country than Egypt. Indeed, taking a glance at the diseases which are ascertained or supposed to be originated by micro.organisms some are cosmopolitan and common also to all civilised countries, as tuberculosis, diphtheria, enteric fever, pneumonia, influenza, and so on; others exist in Egypt as well as in many other warm countries, but their frequency being much greater in the latter than in Egypt there is in such countries a better field for study than in Egypt itself in the case of diseases like lepra, ainhum, and beri-beri.

of the great plagues of man, oriental pestis, or bubonic pestis, has not been for more than half a century seen in Figypt. Yellow fever has never been known in Egypt, and only cholera is still a periodical visitor, though, as I have said, not a frequent one. Perhaps of the diseases that in Egypt originate from micro-organisms only bilious fever claims particular attention as regards its importance, gravity, and the frequent occurrence of epidemics of it, while it is a disease peculiar to Egypt and other warm countries.

Elephantiasis, though its bacteriological origin has been sought, is, in some of its forms at least, certainly connected with filaria. The question as to whether or not dysentery is caused by amœbæ has still to be answered. Chronic diarrhcea, frequent among the natives, must be studied in relation to rhabdonema. Chyluria, chylous hydrocele, lymph scrotum, and other kinds of lymphorrhagia, all disenses very common in Egypt, are certainly caused by filaria in the vascular system which pours its embryos into the blood circulation. It is probable that more than one species of filaria sanguinis exist in Egypt, if not precisely in indigenous subjects, in many of the large number of individuals who come from Nubia, and probably those species that up to now are not indigenous in Egypt may become so in time for want of due attention to prevent their spread. Thus zoo-parasites offer special opportunities for study in Egypt, or rather in Africa, of which Tigypt is the first representative, for its being older on the way towards civilisation. So if there is a branch of pathology that is worthy the attention of the rulers in Egypt for being cultivated in a special manner it is zoo-parasitology. The importance of this branch of medicine being considered in relation to the occurrence of epidemics of cholera, to whose extension, sererity, and large death-rate these patients contribute, I cannot doubt the alterations that obtain in the intestines of a large number of natives, in consequence of having been subject to dysentery, bilharzia, ankylostoma rhabdonema, which by themselves are already common or ordinary causes of morbidity and mortality in Egypt and in Africa, are an additional cause of mortality from cholera.

Pellagra, which from private information which I had from my friend Dr. Sandwith of Cairo, has been found lately to be rather frequent among the natives, is more likely to be a disease produced by an alteration of food of toxic nature than a bacteriological disease.

Poplar and Stepney Sick Asylum.-During the year ended last Lady Day, 3567 patients were admitted, 2934 were discharged, and 537 died ; at the end of the year there were .735 remaining. In July, 1895, Mr. Charles Spurrell, F.R ('.S. Fr.g., was elested medical superintendent in succession to Mr. W. H. Pearce. New pavilions were opened last September. The avernge cost of each patient for mainterance was $6 s .5 d$. per week.

\section{IS MITRAL REGURGITATION FROM VALVULAR DISEASE COMMON OR SERIOUS ? 1}

\author{
BY THEODORE FISHER, M.D. LOND.,
}

PATHOLOGIST TO THE BRISTOL ROYAL INFIRMARY AND PHYSICIAN TO OLT-PATIENTS TO THE BRISTOL HOSPITAL FOR SICK CHILDREN AND WOMEN.

IT is well known that mitral regurgitation from valvular disease appears to be much more frequent at the bedside than the post-mortem room would lead one to suppose, yet there is possibly little idea in the minds of the majority of the practitioners of medicine how uncommon the examination of necropsy records proves it to be. Mitral regurgitation from valvular disease conveys the idea of leakage due to deformity of the flaps of the mitral valve, presumably mainly of the large anterior flap, since the posterior division is so small. Mere thickening of the flaps to a slight extent cannot be a lesion of sufficient importance to account for death, since there is no reason why thickening without deformity should lead to regurgitation. Moreover, in the reports of post-mortem examinations written by the inexperienced the word "thickening," as applied to the mitral valve, seems often to be an adjective suggested by the fact that the patient is known to have died from cardiac disease and that it is consequently thought that something wrong with one or another valve must be discovered. When, therefore, I speak of mitral regurgitation dne to valvular disease it will be understood that $I$ do not refer to such thickening but to actual deformity.

Before referring to the results of the examination of postmortem records one or two clinical facts bearing upon the subject of mitral regurgitation may be considered. A systolic murmur heard at the apex of the heart we know may not uncommonly appear during a first attack of rheumatism, yet possibly we are not always justified in saying that endocarditis is present, or at least that the murmur is produced by an endocarditis that has caused deformity of the flaps of the mitral valve. Deformity must take some time to develop, yet so soon is the murmur sometimes audible that it seems far more reasonable to suppose that dilatation of the left ventricle has occurred. If in an attack of rheumatism in which a systolic murmur has been heard pericarditis supervenes and carries off the patient, we may find evidence on post-mortem examination of the existence of endocarditis in the presence of a row of fine, bead-like vegetations lining the flaps of the mitral valve, but the flaps themselves will be as well shaped and as supple as in perfect health. One can hardly suppose that the minute, bead-like bodjes have interfered with the competency of the valve, and there is certainly no deformity that can have led to regurgitation. Although it is not easy to estimate small degrees of dilatation of the left ventricle in the post-mortem room, it is reasonable to conclude, in the absence of sufficient lesion of the flaps of the valve to give rise to a regurgitant murmur, that the dilatation present has been sufficient to occasion the murmur. Dilatation of the left ventricle occurring during attacks of rheumatism, while probably sufficient in amount to give rise to a systolic apex murmur, need not necessarily be so great as to give definite signs of its existence at the bedside. Yet there is one clinical fact that has some bearing upon this point. It is the frequency of a systolic murmur audible over the pulmonary area. The existence, of this murmur (the frequent presence of which any not familiar with the fact may easily prove for themselves) can hardly be ascribed to endocarditis of the pulmonary valves. Minute bead-like bodies like those on the mitral or aortic valves may sometimes be found on the tricuspid and pulmonary valves in cases of death from rheumatic pericarditis, but they are rare, whereas the pulmonary systolic murmur is common. The small beads of rheumatic endocarditis one would also think to be too small to give rise to a murmur. Dr. Foxwell has given an admirable explanation of the pulmonary systolic murmur. He ascribes it to dilatation of the right ventricle mainly in the region of the conus arteriosus. My experience

I A paper read before the Bristol Medico-Chirurgical Society on 